\title{
DISENTANGLING DIVERSITY PATTERNS IN CUBAN SCORPIONS (ARACHNIDA: SCORPIONES)
}

\author{
Desenredando los patrones de diversidad de los \\ escorpiones cubanos (Arachnida: Scorpiones)
}

\author{
André Felipe de Araújo Lira ${ }^{1 *}$, Stênio Ítalo Araújo Foerster ${ }^{2}$, \\ Adriano Medeiros DeSouza ${ }^{3}$, and Luis F. de Armas $^{4}$
}

\begin{abstract}
${ }^{1}$ Programa de Pós-Graduação em Biociência Animal, Universidade Federal Rural de Pernambuco, Recife, Brazil. orcid.org/0000-0002-8443-4126. ${ }^{2}$ Department of Zoology, Institute of Ecology and Earth Sciences, University of Tartu, Tartu, Estonia. (1) orcid.org/0000-0001-9639-9009, stenioit@gmail.com. 3Programa de Pós-Graduação em Ciências Biológicas, Universidade Federal da Paraíba, Cidade Universitária, João Pessoa, Brazil. (1) orcid.org/0000-0001-6701-4640, adriendrix@gmail.com. ${ }^{4}$ Instituto de Ecologia y Sistematica, CITMA, La Habana, Cuba. (1) orcid.org/0000-0002-9096-3382, luisdearmas1945@gmail.com. *Corresponding author: andref.lira@gmail.com
\end{abstract}

[Recibido: 8 de junio, 2021. Aprobado para publicación: 21 de noviembre, 2021]

\section{ABSTRACT}

The assembly of communities is often viewed as a process involving the dispersal of species from a regional pool. An oceanic island provides a unique opportunity to test such a hypothesis and many others related to the patterns and processes behind biodiversity. Our aim was to investigate the patterns of scorpion diversity in the Cuban archipelago, using biotic and abiotic variables and their interactions as explanatory features. We use biotic and abiotic variables related to vegetation, climate and topography characterize the landscape of the Cuban archipelago. In this way, we analyze the patterns of beta diversity of the scorpions, verifying the effects of the variables alone and together. Scorpion fauna of the Cuban archipelago comprises 61 species, grouped into nine genera and two families: Buthidae and Diplocentridae. The interplay between biotic and abiotic variables explained scorpion species composition, especially when spatial predictors were considered. Climatic and spatial predictors affected scorpion beta diversity in terms of richness difference. These patterns are discussed emphasizing the role of biotic and abiotic environmental features and their interactions on the mechanisms of scorpion biodiversity generation and maintenance in Cuban archipelago.

Keywords: species distribution, beta diversity, landscape ecology, island biogeography, Greater Antilles.

\section{RESUMEN}

El ensamblaje de comunidades se considera a menudo como un proceso que implica la dispersión de especies procedentes de una fuente regional. Una isla oceánica brinda una oportunidad única para probar tal hipótesis y muchas otras relacionadas con los patrones y procesos detrás de la biodiversidad. Nuestro objetivo fue investigar los patrones de diversidad de los escorpiones en el archipiélago cubano, utilizando variables bióticas y abióticas y sus 
interacciones como características explicativas. Se utilizaron variables bióticas y abióticas relacionadas con la vegetación, el clima y la topografía que caracterizan el paisaje del archipiélago cubano. De esta forma, se analizaron los patrones de diversidad beta de los escorpiones, verificando los efectos de las variables solas y juntas. La fauna de escorpiones del archipiélago cubano comprende 61 especies, agrupadas en nueve géneros y dos familias: Buthidae y Diplocentridae. La interacción entre las variables bióticas y abióticas explicó la composición de las especies, especialmente cuando se consideraron predictores espaciales. Los predictores climáticos y espaciales afectaron la diversidad beta en términos de diferencia de riqueza. Estos patrones se discuten enfatizando el papel de las características ambientales bióticas y abióticas y sus interacciones en los mecanismos de generación y mantenimiento de la biodiversidad de los escorpiones en el archipiélago cubano.

Palabras clave: distribución de especies, diversidad beta, ecología del paisaje, biogeografía insular, Antillas Mayores.

\section{INTRODUCTION}

Biological diversity is modulated by several processes that contribute to the addition or removal of species across time and space, which may include speciation, dispersion, and extinction events (Ricklefs, 2004). Most of these processes are associated with biotic (e.g., land cover and vegetation structure) or abiotic (e.g., climate and topography) features (Moura et al., 2016; Fergnani \& Ruggiero, 2017; Alves et al., 2018). Biotic and abiotic factors are naturally related to each other. Climate, for instance, can affect species richness indirectly via its effect on vegetation structure and dynamics (Stein et al., 2014). In turn, climate and vegetation can be a product of topographic heterogeneity, leading to an additional source of variability that affects the patterns of species diversity (Ruggiero \& Hawkins, 2008; Stein et al., 2014). Frequently, previous studies have tried to explain species diversity using only abiotic factors (e.g., Vasconcelos et al., 2010; Nemésio \& Vasconcelos, 2013; Valdujo et al., 2013), giving a little attention to the potential effects of biotic counterparts (Qian et al., 2009; Jiménez-Valverde et al., 2010; Carvalho et al., 2011).

Therefore, it is important to study the unique and shared contributions of abiotic and biotic factors to biodiversity patterns (Ray-Mukherjee et al., 2014). These factors do not necessarily drive species diversity in similar ways; instead, their importance depends on the group and taxonomic level studied, as well as the spatial scale and biogeographical history of the contextualized region (Belmaker \& Jetz, 2011; Rodriguez-Artigas et al., 2016). Understanding their relative contribution is therefore crucial to improve our knowledge of the effect of global climate and land use changes on biodiversity (Jetz et al., 2007; Hof et al., 2011). In addition, the natural dynamics of diversity patterns have been represented more efficiently by beta diversity $(\mathrm{d} \beta)$ measurements because it describes the species variation between habitats and interacts directly with species richness gradients, which are influenced by environmental aspects at both the local and regional scales (Soininen et al., 2018).

Landscape-scale studies on oceanic islands have a major advantage over comparable studies on continental systems (Irl et al., 2015; Rominger et al., 2016; Liu et al., 2018). The presence of a large share of species that have evolved in situ allows the inference of general drivers of speciation from spatial patterns of diversity (Irl et al., 2015; Mittelbach \& Schemske, 2015). Thus, spatial distribution within a given oceanic island can provide valuable insights regarding drivers of biodiversity patterns at the landscape scale, depicting important implications for conservation (Richardson \& Whittaker, 2010; Socolar et al., 2016). 
In island systems, competition for resources drives ecological niche divergence (Schluter, 2000; Losos, 2010). Moreover, the competing species increases, ecological opportunity (niche availability) decreases, and the pace of diversification slows (Sepkoski, 1978; Schluter, 2000; Mahler et al., 2010). Therefore, bigger islands tend to have more ecomorphs, suggesting that the degree of niche filling depends on the environmental properties of the island (e.g., area and habitat diversity) (MacArthur \& Wilson, 1967; Mahler et al., 2013). For example, the Cuban archipelago that comprises an important part of the Caribbean Islands hotspot (Myers et al., 2000; Mittermeier et al., 2005), exhibiting a significant taxa diversity and endemism rate in the region (Borroto-Páez \& Mancina, 2017; Denis et al., 2018). These patterns are results of a complex geological history that produced sequences of isolations and reconnection along thousand years generating the emergence of groups with strong adaptive radiation (Iturralde-Vinent \& MacPhee, 1999; Hedges, 2006; Denis et al., 2018).

Animals with low vagility, long life cycles, and microhabitat specialization, such as scorpions, offer a good model for studying the patterns and processes of biological diversity (e,g., Foord et al., 2015; Esposito \& Prendini, 2019; Foerster et al., 2019; Lira et al., 2019a). These arachnids possess high environmental requirements that are not distributed randomly throughout the landscape (Polis, 1990). Previous studies provide evidences that assemblages of these arachnids are driven by several environmental factors, which includes temperature, precipitation, vegetation structure, as well as by the complex interaction among these factors (e.g., Warburg \& Ben-Horin, 1981; Prendini, 2005; Foord et al., 2015). For example, Lira et al. (2021a) detected that vegetation cover (biotic variable) is a key factor to scorpion diversity in a Brazilian Atlantic Rainforest. In addition, vegetation structure also plays a role to maintenance of scorpion assemblage on Seasonal Dry Tropical Forest (Foerster et al., 2020; Lira et al., 2021b). At the regional scale, Lira et al. (2019a) investigated the effect of the bioclimatic gradient between wet and dry forests on scorpion assemblages in Brazil and found that temperature and precipitation (abiotic variables) were the major explanatory factors of scorpion richness and $\mathrm{d} \beta$, which increased toward the dry forest gradient. Finally, topographic factors, such as elevation may exert influence on scorpion species distribution ranges (Prendini \& Bird, 2008; Campón et al., 2014). Thus, the sensitivity of these animals at different scales makes them a good model for studies that focus on analyzing diversity patterns.

\section{OBJECTIVES}

- Considering the higher vegetation and topography complexity of Cuban archipelago, our aim was determining large-scale patterns from beta diversity of Cuban scorpions, using the association and interaction between abiotic (climatic and topographic measures) and biotic (vegetation complexity) factors.

\section{MATERIALS AND METHODS}

\section{Study area}

The Cuban archipelago $\left(23^{\circ} 18^{\prime} \mathrm{N}-80^{\circ} 54^{\prime} \mathrm{W}\right)$ is composed by the main island of Cuba, the Isla de la Juventud (previously Isle of Pines) who is the second-largest Cuban island and almost 4000 other smaller insular territories. Around the Cuban main island (Isle of Cuba), there are four groups of keys and smaller islands: in the northwest, De los Colorados archipelago; in the middle north, Sabana-Camagüey archipelago, also known as Jardines del Rey; in the southwest, Canarreos archipelago; and in the southeast, Jardines de la Reina archipelago. 
Approximately one-fourth of the Cuban territory is mountainous, with four principal orographic systems: in the west, Guaniguanico (comprising Sierra de los Órganos and Sierra del Rosario); in the central southern region, Guamuhaya, sometimes called Escambray (comprising Alturas de Trinidad and Banao); in the southeastern region, Sierra Maestra (comprising Sierra Maestra s.s. and Sierra de La Gran Piedra); and Nipe-Sagua-Baracoa in the northeastern region. The highest elevation, Pico Turquino (1974 m a.s.1.), is located in Sierra Maestra, where several summits are over $1400 \mathrm{~m}$ a.s.l, with the western and central regions having elevations lower than 1200 m a.s.l. (González-Alonso \& Armas, 2007).

For most plants and animals, the eastern region of Cuba (provinces of Guantánamo, Santiago de Cuba, Holguín, and Granma) is the most biodiverse, likely because of its geological and ecological complexity and arid ecosystems; however, this region also has the largest and most well-preserved tropical rainforests (González-Alonso \& Armas, 2007).
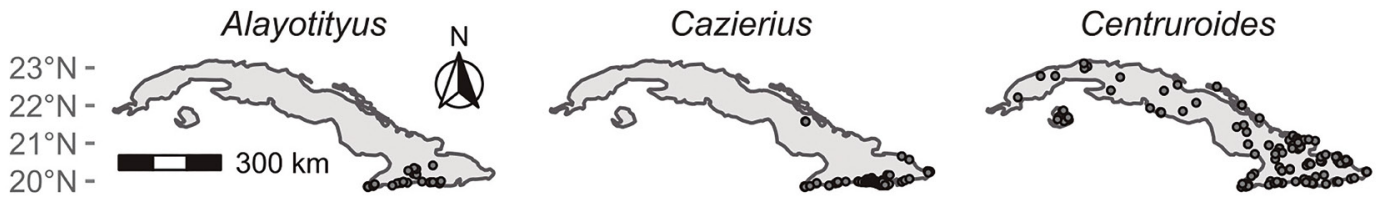

Cryptoiclus
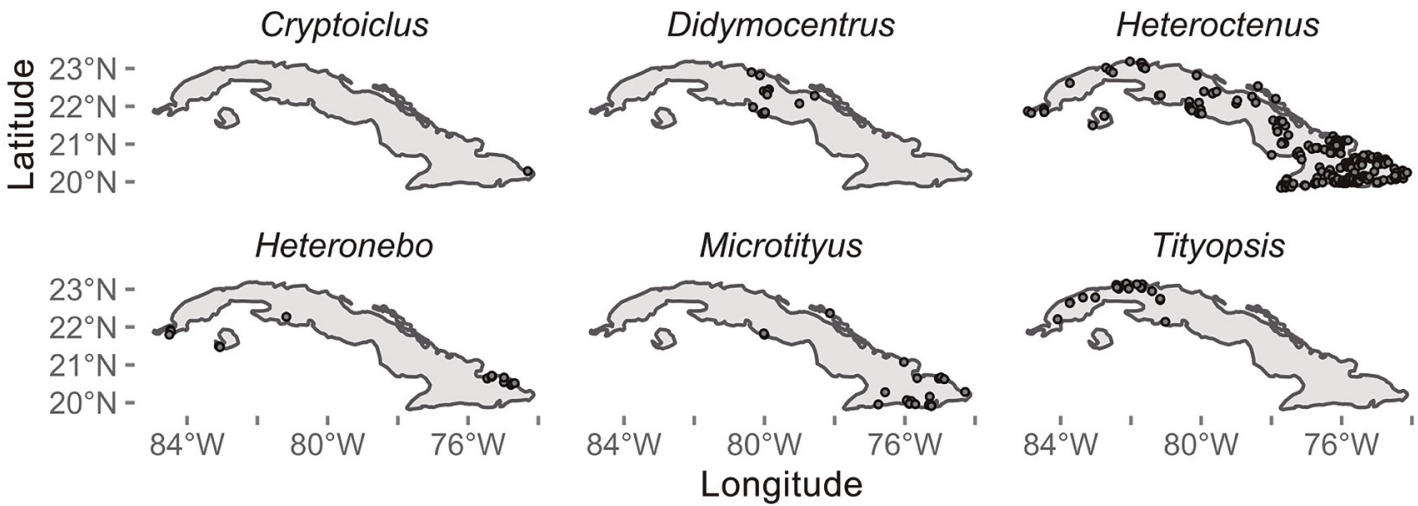

Figure 1. Geographical distribution of scorpion genera over the Cuban archipelago.

\section{Species data}

To achieve a representability that was close to the real scenario for the occurrence areas of the Cuban scorpion species, we used data obtained from the following two sources: the arachnological collection of the Institute of Ecology and Systematics, Havana, Cuba and previous literature records (Appendix I). All occurrences were inspected carefully to detect and correct any problems associated with taxonomic misidentification, duplication, and geographically discordant localities. The data set used in this study comprises 57 scorpion species (excluding four introduced species), which are grouped into nine genera and two families: Buthidae C. L. Koch, 1837 and Diplocentridae Karsch, 1880 (Appendix I). 
Buthids scorpions are represented by five genera and 42 species, while diplocentrids were represented by 15 species grouped into four genera (Appendix I). Diplocentrid scorpions were represented by genera Cazierus Francke, 1978, Cryptoiclus Teruel \& Kovarik, 2012, Didymocentrus Kraepelin, 1905, and Heteronebo Pocock, 1899, with Cryptoiclus being monotypic and Cazierus being more specious (Appendix I). In addition, the records of exotic species found in the Cuban archipelago were excluded from our analysis: Isometrus maculatus (DeGeer, 1778), Centruroides gracilis (Latreille, 1804), Centruroides edwardsii (Gervais, 1843) and Centruroides margaritatus (Gervais, 1841). We established a spatial grid with cell size of $25 \times 25 \mathrm{~km}$, cropping it according to a shapefile of the Cuban archipelago. This cell size was chosen to adequately capture the environmental features from the raster layers (e.g., minimizing the proportion of missing data), taking into account the low-dispersal capabilities of scorpions (Bryson Jr et al., 2016) and also their specificity in terms of microhabitat use (Prendini, 2001). We annotated the scorpion species for each grid cell, and for those cells, we extracted a set of environmental predictors (Table I) using the 'raster' package (Hijmans, 2019) in the R environment ( $\mathrm{R}$ Core Team, 2020). To simplify the procedures adopted in this study, we interpreted each grid cell containing scorpion occurrence as an individual biological assemblage.

Table I. Environmental predictors used in the analysis of the present study to explain the diversity patterns in scorpions on the Cuban archipelago

\begin{tabular}{|c|c|c|c|}
\hline Variable & Predictor class & Description & Raster source \\
\hline Land cover diversity & $\begin{array}{l}\text { Vegetation } \\
\text { Complexity }\end{array}$ & $\begin{array}{l}\text { Expressed as the entropy level } \\
\text { (Shannon's index) computed } \\
\text { for the land cover classes } \\
\text { within each grid cell. }\end{array}$ & Latham et al. (2014) \\
\hline Canopy standard deviation & $\begin{array}{l}\text { Vegetation } \\
\text { Complexity }\end{array}$ & $\begin{array}{l}\text { Average standard deviation } \\
\text { of canopy height (in meters) } \\
\text { measured within each grid cell. }\end{array}$ & Simard et al. (2011) \\
\hline Canopy range & $\begin{array}{l}\text { Vegetation } \\
\text { Complexity }\end{array}$ & $\begin{array}{l}\text { Average amplitude of canopy } \\
\text { height (in meters) measured } \\
\text { within each grid cell. }\end{array}$ & Simard et al. (2011) \\
\hline Annual mean temperature & Climatic & $\begin{array}{l}\text { Average annual mean } \\
\text { temperature }\left({ }^{\circ} \mathrm{C}\right) \text { calculated for } \\
\text { each grid cell. }\end{array}$ & Brown et al. (2018) \\
\hline Temperature annual range & Climatic & $\begin{array}{l}\text { Average annual temperature } \\
\left({ }^{\circ} \mathrm{C}\right) \text { range observed per grid } \\
\text { cell. }\end{array}$ & Brown et al. (2018) \\
\hline Annual precipitation & Climatic & $\begin{array}{l}\text { Mean annual precipitation } \\
\text { range (mm/year) observed per } \\
\text { grid cell. }\end{array}$ & Brown et al. (2018) \\
\hline Precipitation range & Climatic & $\begin{array}{l}\text { Mean difference between the } \\
\text { precipitation of the wettest } \\
\text { quarter and the precipitation } \\
\text { observed on the driest quarter } \\
\text { ( } \mathrm{mm} / \text { year). }\end{array}$ & Brown et al. (2018) \\
\hline Elevation range & Topography & $\begin{array}{l}\text { Average amplitude of elevation } \\
\text { per grid cell, given in meters. }\end{array}$ & USGS (1996) \\
\hline $\begin{array}{l}\text { Elevation } \\
\text { (coefficient of variation) }\end{array}$ & Topography & $\begin{array}{l}\text { Average value of coefficient } \\
\text { of variation calculated for each } \\
\text { grid cell (meter). }\end{array}$ & USGS (1996) \\
\hline
\end{tabular}




\section{Environmental predictors}

We split the list of environmental predictors into three matrices that included variables related to 1) vegetation complexity, 2) climatic features, and 3) topographic constraints (Table I). Vegetation variables were generated from raster layers provided by the Global Land Cover-SHARE database (Latham et al., 2014), and the 3D Global Vegetation Map database (Simard et al., 2011). Similarly, we used the bioclimatic raster files from Paleoclim (Brown et al., 2018), and those from the GTOPO30 project (USGS, 1996) to generate the variables related to climate and topography, respectively. All raster files were downloaded at a pixel resolution of 30 arc-sec and resampled in the 'raster' $\mathrm{R}$ package to assure their equality in terms of spatial extent and map projection (EPSG:4326). Vegetation complexity was represented by vegetation structure metrics (e.g., the standard deviation and range interval of the canopy height) and also by the land cover diversity within each grid cell containing scorpion occurrences (Table I). In turn, land cover diversity was expressed by the Shannon's entropy index calculated from the land cover classes sampled within each grid cell, using the 'vegan' R package (Oksanen et al., 2019). The remaining variables related to climate and topography (Table I) were computed using simple statistic metrics (e.g., mean, range interval, coefficient of variation) implemented in base packages of the R software.

\section{Data analysis}

We first determined the total $\mathrm{d} \beta$ ( $\beta$ total) among scorpion assemblages distributed over the Cuban archipelago, and then decomposed this metric to obtain the relative contribution of species replacement and richness difference-the two components of the total $\mathrm{d} \beta$ (sensu Legendre, 2014). Both procedures were conducted in the 'adespatial' $\mathrm{R}$ package (Dray et al., 2018), taking the assemblage matrix (grid cells $\times$ scorpion species) as input and applying the Podani-family of Sørensen dissimilarity index (Legendre, 2014). This family of dissimilarity decomposition was chosen because it produces Euclidean matrices of richness difference that is suitable for constrained ordination methods (Legendre, 2014) required for the subsequent analyzes present in this study. In addition, the species replacement matrix resulted from this procedure can also present Euclidean behavior after a simple square root transformation (Legendre, 2014; Borcard et al., 2018).

Stochastic processes, such as dispersion, may have a relevant role in the structuring of biological assemblages (Padial et al., 2014) especially in low-dispersal taxa (Heino, 2013). Therefore, we included a set of orthogonal spatial predictors in the downstream analysis to account for potential effects of stochastic process over the pattern of $\beta$-diversity presented by scorpion assemblages. Spatial predictors were generated using Distance-Based Moran's Eigenvector Maps (dbMEM: Borcard and Legendre, 2002; Borcard et al., 2004; Dray et al., 2006). Following the procedures described in Moura et al. (2016), we used the 'adespatial' $\mathrm{R}$ package to perform the dbMEM analysis, recovering all spatial descriptors with positive spatial autocorrelation structure, which are compatible for constrained ordination methods (Borcard \& Legendre, 2002). After that, we applied a variation partitioning analysis to measure the unique and shared effects of environmental and spatial predictors on the variability of 1) assemblage dissimilarity, 2) species replacement, and 3) richness difference among scorpion assemblages. To access the statistical significance of combined fractions in explaining the variability in the response matrices, we used a series of distance-based redundancy analysis (dbRDA: McArdle \& Anderson, 2001) followed by permutation tests (1,000 permutations), both implemented in the 'vegan' $\mathrm{R}$ package. The isolated contribution of each predictor class (Table I), as well as the variability in the response matrices explained solely 
by spatial predictors, were tested using partial-dbRDA and the same permutation tests mentioned above. In both cases (dbRDA and partial-dbRDA) we applied the Lingoes correction to avoid the generation of negative eigenvalues during the modeling processes (Legendre and Anderson, 1999). We quantify the relative contribution of shared and non-shared explained fractions using the adjusted coefficient of determination $\left(\mathrm{R}^{2} \mathrm{adj}\right)$ proposed by Peres-Neto et al. (2006). Prior to variation partitioning, all environmental predictors were $\log (\mathrm{x}+1)$ transformed and checked for collinearity problems using variance inflation factor (VIF) obtained in the 'usdm' $\mathrm{R}$ package (Naimi, 2015). We assume a VIF less than 10 as an indicator of negligible collinearity effects during the modeling processes (Zuur et al., 2009).

\section{RESULTS}

Buthidae species showed a widespread distribution in the Cuban archipelago, species from Heteroctenus Pocock, 1893 and Centruroides Marx, 1890 genera were found in practically all Cuban territory. In contrast, some buthid genera such as Tityopsis Armas, 1974 and Alayotityus showed a more restricted distribution and were found on the western and eastern sides of the Cuban archipelago, respectively (Fig. 1). Diplocentrid scorpions are also found throughout the Cuban territory. However, their genera exhibited a clumped distribution pattern, representatives from Cazierus and Cryptoiclus genus were restricted to eastern side of the Cuban archipelago (Fig. 1). Species richness ranged from one to nine species per grid cell, with a slightly increase in the observed number of species towards the southern region of the Cuban archipelago (Fig. 2).

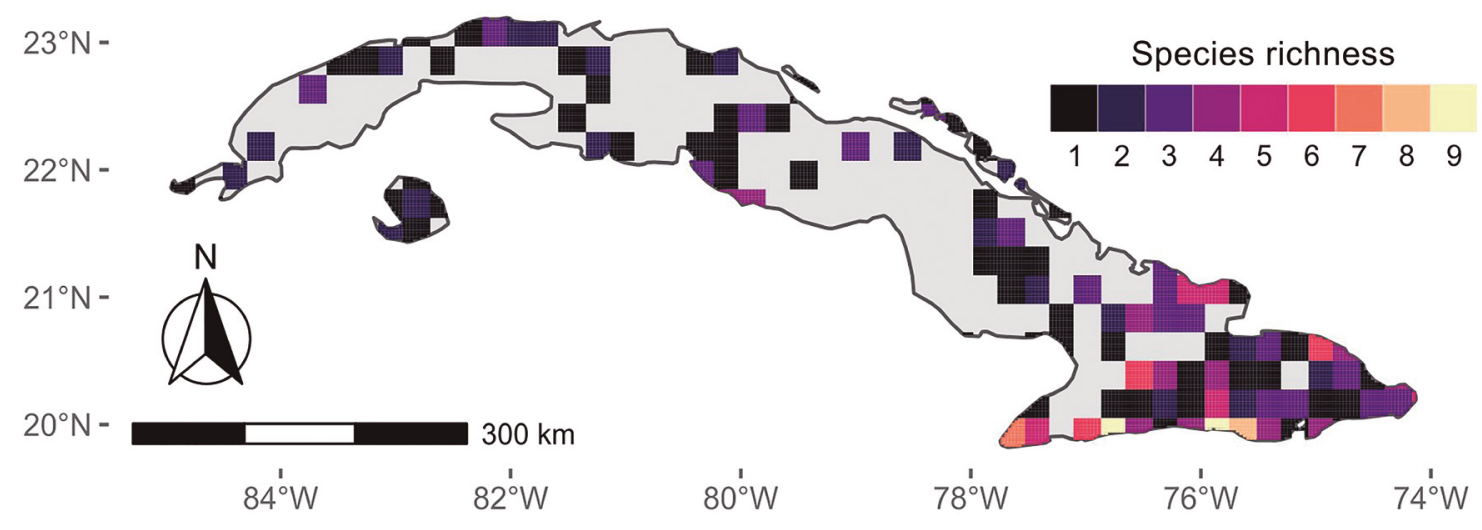

Figure 2. Spatial distribution of scorpion richness over the Cuban archipelago. Species richness is given as the number of scorpion species counted per grid cell at $25 \times 25 \mathrm{~km}$ pixel resolution.

Species replacement accounted for $56 \%$ of the total $\beta$-diversity estimated from scorpion assemblages $(\beta$ total $=0.358)$, while the remaining $44 \%$ was attributed to the richness difference component. The average dissimilarity observed among scorpion assemblages was estimated in $0.716 \pm 0.305$ (mean \pm standard deviation), whereas the mean levels of species replacement and richness difference were quite similar (Fig. 3). 


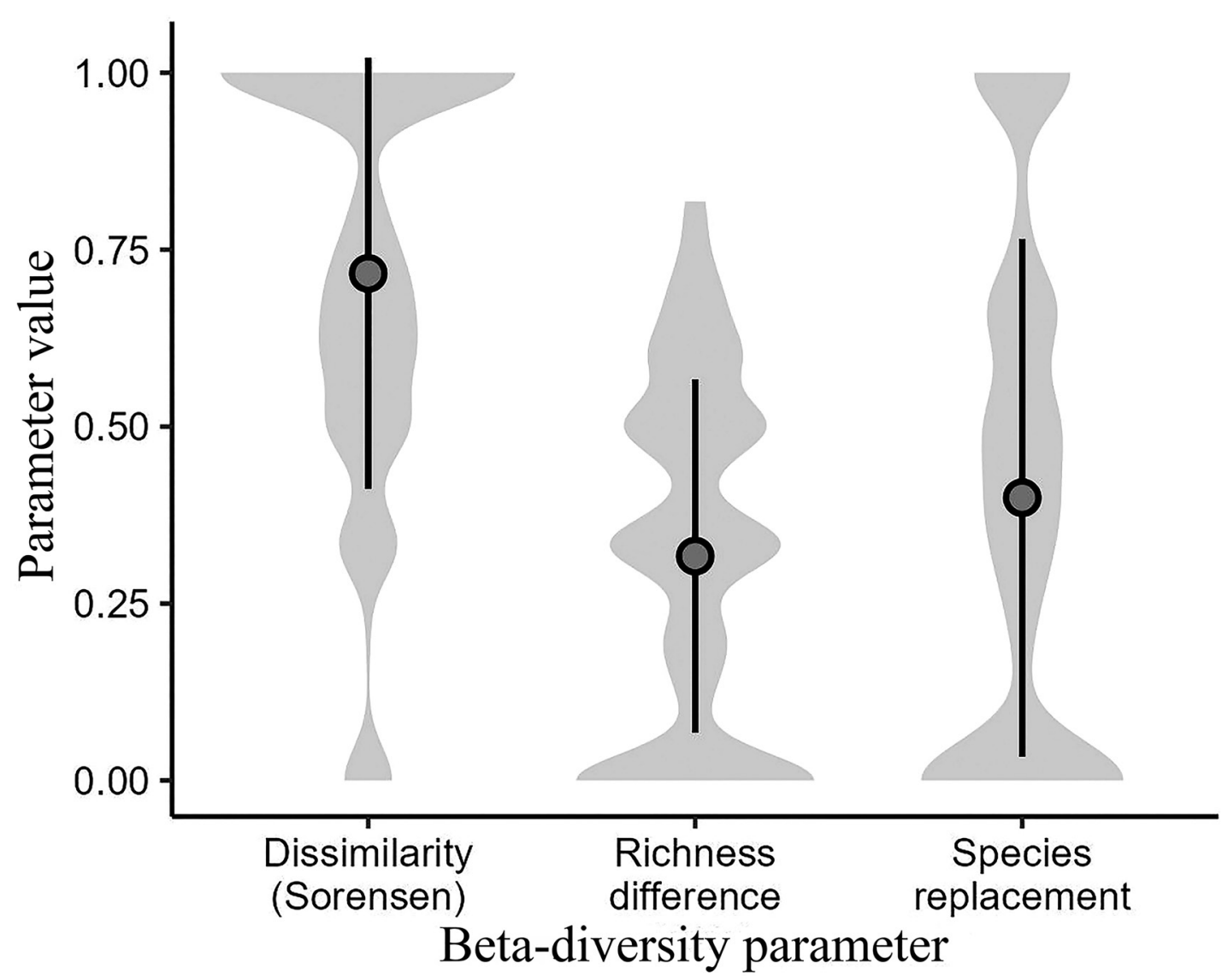

Figure 3. Graphical summary of $\beta$-diversity parameters (Sørensen dissimilarity, richness difference, and species replacement) observed for the scorpion assemblages of Cuban archipelago. Mean values and standard deviation are illustrated by dots and vertical bars, respectively, while the distributional structures of each $\beta$-diversity parameter are represented by grey shades.

Together, the set of environmental and spatial predictors explained $7 \%$ of the dissimilarity observed among scorpion assemblages (Table II). This dissimilarity could be better explained when environmental and spatial predictors were combined, although the percentual contribution resulting from these combinations were relatively low (2-7\%, Table II). Individually, the dissimilarity among scorpion assemblages could be explained only by spatial predictors $\left(\mathrm{R}^{2} \mathrm{adj}=0.047, p<0.05\right.$, Table II). Different combinations of environmental and spatial predictors explained only $0.1 \%$ to $0.4 \%$ in the levels of species replacement present among scorpion assemblages (Table II). Levels of richness difference among scorpion assemblages could not be explained solely by vegetation complexity, although isolated effects were detected for climate, spatial structure and topography (Table II). In addition, 10-28\% of the variation in richness difference could be attributed to the mixed effects between environmental and spatial predictors (Table II). Environmental variables did not present collinearity problems (VIF < 4.18). 
Table II. Statistical summary from the variation partitioning analysis of assemblage dissimilarity, species replacement, and richness difference observed among scorpion assemblages in the Cuban archipelago

\begin{tabular}{lccccccc}
\hline \multirow{2}{*}{ Predictor class } & \multicolumn{3}{c}{ Assemblage dissimilarity } & \multicolumn{2}{c}{ Species replacement } & \multicolumn{2}{c}{ Richness difference } \\
\cline { 2 - 6 } & d.f. & $\mathrm{F}$ & $\mathrm{R}^{2} \mathrm{adj}$ & $\mathrm{F}$ & $\mathrm{R}^{2}$ adj & $\mathrm{F}$ & $\mathrm{R}^{2} \mathrm{adj}$ \\
\hline Individual effects & & & & & & & \\
VEG & 3 & 1.145 & 0.005 & 1.016 & 0.001 & 0.915 & 0.000 \\
CLI & 4 & 1.096 & 0.004 & 0.979 & 0.000 & 5.245 & $\mathbf{0 . 1 5 5}$ \\
TOP & 2 & 0.882 & 0.000 & 0.979 & 0.000 & 3.135 & $\mathbf{0 . 0 3 9 9}$ \\
SPA & 30 & 1.177 & $\mathbf{0 . 0 4 7}$ & 1.007 & 0.002 & 1.744 & $\mathbf{0 . 1 5 3}$ \\
Shared effects & & & & & & & \\
CLI + VEG & 7 & 1.424 & $\mathbf{0 . 0 2 5}$ & 1.016 & $\mathbf{0 . 0 0 1}$ & 2.854 & $\mathbf{0 . 1 0 2}$ \\
CLI + TOP & 6 & 1.360 & $\mathbf{0 . 0 1 9}$ & 1.005 & $<0.001$ & 3.650 & $\mathbf{0 . 1 2 2}$ \\
CLI + SPA & 34 & 1.248 & $\mathbf{0 . 0 6 9}$ & 1.013 & $\mathbf{0 . 0 0 4}$ & 1.552 & $\mathbf{0 . 1 4 1}$ \\
VEG + TOP & 5 & 1.459 & $\mathbf{0 . 0 2 0}$ & 1.007 & $<0.001$ & 3.819 & $\mathbf{0 . 1 1 0}$ \\
VEG + SPA & 33 & 1.256 & $\mathbf{0 . 0 7 0}$ & 1.014 & $\mathbf{0 . 0 0 4}$ & 1.395 & 0.103 \\
TOP + SPA & 32 & 1.212 & $\mathbf{0 . 0 5 6}$ & 1.009 & $\mathbf{0 . 0 0 2}$ & 1.600 & $\mathbf{0 . 1 4 4}$ \\
CLI + VEG + TOP & 9 & 1.320 & $\mathbf{0 . 0 2 5}$ & 1.009 & 0.001 & 2.833 & $\mathbf{0 . 1 2 6}$ \\
CLI + VEG + SPA & 37 & 1.248 & $\mathbf{0 . 0 7 4}$ & 1.010 & $\mathbf{0 . 0 0 3}$ & 1.971 & $\mathbf{0 . 2 4 0}$ \\
CLI + TOP + SPA & 36 & $\mathbf{1 . 2 2 5}$ & 0.066 & 1.007 & 0.002 & 2.244 & $\mathbf{0 . 2 8 2}$ \\
VEG + TOP + SPA & 35 & 1.234 & $\mathbf{0 . 0 6 7}$ & 1.012 & $\mathbf{0 . 0 0 4}$ & 1.464 & 0.125 \\
All & 39 & 1.226 & $\mathbf{0 . 0 7 2}$ & 1.008 & $\mathbf{0 . 0 0 3}$ & 2.135 & $\mathbf{0 . 2 8 0}$ \\
Residuals & 0 & - & 0.928 & - & 0.997 & - & 0.720 \\
\hline
\end{tabular}

Environmental features were grouped into three classes representing vegetation complexity (VEG), climatic features (CLI) and topography (TOP). Spatial predictors were included as a fourth class of independent variables (SPA). The relative amount of variance explained by each predictor class is given by the unbiased coefficient of determination ( $R^{2}$ adj), in which statistically significant values $(\mathrm{P}<0.05)$ are presented in bold.

\section{DISCUSSION}

This study assessed the isolated and combined contributions of vegetation, climatic and topographic variables regarding the diversity pattern of scorpion assemblages in the Cuban archipelago. We found vegetation, climatic, and spatial predictors combined influences in scorpion species composition and $\mathrm{d} \beta$ pattern. These synergisms between biotic and abiotic variables in scorpion composition have also been described in previous studies (Due and Polis, 1986; Prendini, 2001; Foord et al., 2015; Lira et al., 2019a). Our results favor the rationale of a filter compounded by the interplay between biotic (e.g., vegetation complexity) and abiotic (e.g., climate and topography) components that determine which scorpion species successfully colonize and coexist at a local site.

Scorpions belong to an arthropod predator group with low dispersion capacity and their ecological requirements are likely to have a prominent role in the spatial arrangement of their assemblages (Dionisio-da-Silva et al., 2018; Foerster et al., 2019; Lira et al., 2021). For example, Lira et al. (2019a) found that $36 \%$ of scorpion species composition along a $712 \mathrm{~km}$ dry-wet bioclimatic gradient was explained by spatial predictors. In scorpion species of a Brazilian montane forest fragments, $51 \%$ of composition variability was influenced by spatial predictors (Foerster et al., 2019). Therefore, the scorpion bionomical properties could 
be a potential source of variation on the size and composition of scorpion assemblages along the Cuban archipelago. Cuban scorpion fauna is composed by eurytopic species (e.g., Centruroides spp.) (Teruel \& Kovařík, 2012) and by stenotopic species (e.g., Tityopsis spp.) considered as forest scorpions (Teruel \& Rodríguez-Cabrera, 2020). In this way, scorpion species with limited vagility and lower ecological plasticity may be restricted to small territorial extensions in archipelagos as Cuba. Such interpretations are supported by the effect of spatial distance on the species composition, in which scorpion assemblages in the eastern portion are quite different from those distributed on the western side of the Cuban archipelago (see Fig. 1).

In the Cuban archipelago, the $\mathrm{d} \beta$ of scorpions was explained in similar way by the species replacement component and richness difference. We found a synergism between species richness differences with biotic and abiotic variables. These results indicate that interactions between biotic and abiotic variables act as species filter, allowing the establishment of natural communities according to their environmental requirements. Thus, our finding suggests that the assembly of diversity patterns among scorpion assemblages in the Cuban archipelago may be the result of interplay between ecology and evolution. Besides, the interactions between scorpion intrinsic features, (limited vagility and microhabitat specificity) and the high geological and vegetation complexity of the Cuban archipelago may explain a high number of scorpion species and the $\mathrm{d} \beta$ pattern. Lira et al. $(2019 \mathrm{a}, 2021)$ argue that landscape structure changes such vegetation cover may act as a complex filter, limiting the dispersion of the majority of the scorpion species in Brazilian Atlantic Forest and Caatinga. For example, forest specialists' scorpions are unable to colonize the open forested areas neighboring their forest remnant (Lira et al., 2019b; Lira et al., 2020). Therefore, the larger contribution of species replacement to the overall scorpion $\mathrm{d} \beta$ found in our study indicates that the mechanism behind the assembly of scorpion assemblages in the Cuban archipelago is likely related to the high environmental heterogeneity, as well as the historical and independent colonization events that are intrinsically associated to the biogeographical history of the Cuban archipelago (Crews \& Esposito, 2020).

\section{CONCLUSIONS}

In summary, we found that scorpion species composition and richness differences in the Cuban archipelago depend on biotic and abiotic variables, such vegetation and topography. Our results also indicate that the variables explained a relevant fraction of the scorpion community assembly together rather than individually. Thus, a good practice for future studies focusing on the scorpion community assembly would be to consider both types of variables and analyze them together and separately.

\section{ACKNOWLEDGMENTS}

We are grateful to Fundação de Amparo à Ciência e Tecnologia do Estado de Pernambuco (FACEPE) for granting a postdoctoral scholarship (BFP-0121-2.05/20) to AFAL. We also thank Conselho Nacional de Desenvolvimento Científico e Tecnológico (CNPq) for granting a Master Scholarship to SIAF. Finally, we thanks to two anonymous referees for their valuable comments to improve our manuscript. 


\section{LITERATURE CITED}

Alves, D. M. C. C., J. A. F. Diniz-Filho, K. da Silva e Souza, S. F. Gouveia, \& F. Villalobos. 2018. Geographic variation in the relationship between large-scale environmental determinants and bat species richness. Basic and Applied Ecology, 27: 1-8.

Belmaker, J., \& W. Jetz. 2011. Cross-scale variation in species richness-environment associations: Richness-environment scaling. Global Ecology and Biogeography, 20: 464-474.

Borcard, D., \& P. Legendre. 2002. All-scale spatial analysis of ecological data by means of principal coordinates of neighbour matrices. Ecological Modelling, 153: 51-68.

Borcard, D., P. Legendre, C. Avois-Jacquet, \& H. Tuomisto. 2004. Dissecting the spatial structure of ecological data at multiple scales. Ecology, 85:1826-1832.

Borcard, D., F. Gillet, \& P. Legendre. 2018. Numerical ecology with R. Springer.

Borroto-Páez R., \& C. A. Mancina. 2017. Biodiversity and conservation of Cuban mammals: past, present, and invasive species. Journal of Mammalogy, 98: 964-985.

Brown, J. L., D. J. Hill, A. M. Dolan, A. C. Carnaval, \& A. M. Haywood. 2018. PaleoClim, high spatial resolution paleoclimate surfaces for global land areas. Science Data, 5: 1-9.

Bryson Jr, R. W., W. E. Savary, A. J. Zellmer, R. B. Bury, \& J. E. McCormack. 2016. Genomic data reveal ancient microendemism in forest scorpions across the California Floristic Province. Molecular Ecology, 25: 3731-3751.

Campón, F. F., S. L. Silnik, \& L. A. Fedeli. 2014. Scorpion diversity of the Central Andes in Argentinga. The Journal of Arachnology, 42: 163-169.

Carvalho, J. C., P. Cardoso, L. C. Crespo, S. Henriques, R. Carvalho, \& P. Gomes. 2011. Determinants of beta diversity of spiders in coastal dunes along a gradient of mediterraneity: Spiders along a gradient of mediterraneity. Diversity and Distributions, 17: 225-234.

Crews, S. C., \& L. A. Esposito. 2020. Towards a synthesis of the Caribbean biogeography of terrestrial arthropods. BMC Evolutionary Biology, 20: 1-27.

Denis, D., D. D. Cruz-Flores, \& E. Testé. 2018. Biodiversity in Cuba. Global Biodiversity: Volume 4: Selected Countries in the Americas and Australia.

Dionisio-da-Silva, W., A. F. A. Lira, \& C. M. R. Albuquerque. 2018. Distinct edge effects and reproductive periods of sympatric litter-dwelling scorpions (Arachnida: Scorpiones) in a Brazilian Atlantic forest. Zoology, 129: 17-24.

Dray, S., P. Legendre, \& P. R. Peres-Neto. 2006. Spatial modelling: a comprehensive framework for principal coordinate analysis of neighbour matrices (PCNM). Ecological Modelling, 196: 483-493. 
Dray, S., D. Bauman, G. Blanchet, D. Borcard, S. Clappe, G. Guenard, T. Jombart, G. Larocque, P. Legendre, N. Madi, et al. 2018. adespatial: Multivariate Multiscale Spatial Analysis. $R$ package version $0.3-2$. Available from https:/CRAN.R-project.org/package=adespatial. Accessed 28 November 2018.

Due, A. D., \& G. A. Polis. 1986. Trends in scorpion diversity along the Baja California Peninsula. The American Naturalists, 128: 460-468.

Esposito, L. A., \& L. Prendini. 2019. Island ancestors and new world biogeography: A case study from the scorpions (Buthidae: Centruroidinae). Science Reports, 9: 3500.

Fergnani, P. N., \& A. Ruggiero. 2017. The latitudinal diversity gradient in South American mammals revisited using a regional analysis approach: The importance of climate at extra-tropical latitudes and history towards the tropics. Plos One, 12: e0184057.

Foerster, S. I. A., A. M. DeSouza, \& A. F. A. Lira. 2019. Macroecological approach for scorpions (Arachnida, Scorpiones): $\beta$-diversity in Brazilian montane forests. Canadian Journal of Zoology, 97: 914-921.

Foerster, S. Í. A., A. F. A. Lira, \& C. G. Almeida. 2020. Vegetation structure as the main source of variability in scorpion assemblages at small spatial scales and further considerations for the conservation of Caatinga landscapes. Neotropical Biology and Conservation, 15: 533-550.

Foord, S. H., V. Gelebe, \& L. Prendini L. 2015. Effects of aspect and altitude on scorpion diversity along an environmental gradient in the Soutpansberg, South Africa. Journal of Arid Environments, 113: 114-120.

González-Alonso, H., \& L. F. Armas. 2007. Principales regiones de la biodiversidad cubana. In: González-Alonso, H., editor. Biodiversidad de Cuba. Guatemala: Editorial Polymita, p. 56-69.

Hedges, S. B. 2006. Paleogeography of the Antilles and origin of West Indian terrestrial vertebrates. Annals of the Missouri Botanical Garden, 93: 231-244.

Heino, J. 2013. Environmental heterogeneity, dispersal mode, and co-occurrence in stream macroinvertebrates. Ecology and Evolution, 3: 344-355.

Hijmans, R. J. 2019. raster: Geographic Data Analysis and Modeling. R package version 2.9-5. https://CRAN.R-project.org/package=raster. Accessed 10 November 2019.

Hof, C., M. B. Araújo, W. Jetz, \& C. Rahbek. 2011. Additive threats from pathogens, climate and land-use change for global amphibian diversity. Nature, 480: 516-519.

Irl, S. D. H., D. E. V. Harter, M. J. Steinbauer, D. Gallego Puyol, J. M. Fernández-Palacios, A. Jentsch, \& C. Beierkuhnlein. 2015. Climate vs. topography - spatial patterns of plant species diversity and endemism on a high-elevation island. Journal of Ecology, 103: $1621-1633$. 
Iturralde-Vinent, M. A., \& R. D. E. MacPhee. 1999. Paleogeography of the Caribbean region: Implications for Cenozoic biogeography. Bulletin of the American Museum of Natural History, 238: 1-95.

Jetz, W., D. S. Wilcove, \& A. P. Dobson. 2007. Projected impacts of climate and land-use change on the global diversity of birds. PLoS Biology, 5: e157.

Jiménez-Valverde, A., A. Baselga, A. Melic, \& N. Txasko. 2010. Climate and regional beta-diversity gradients in spiders: dispersal capacity has nothing to say? Insect Conservation and Diversity, 3: 51-60.

Latham, J., R. Cumani, I. Rosati, \& M. Bloise. 2014. Global land cover share (GLC-SHARE) database beta-release version 1.0-2014. FAO: Rome, Italy. Acessed 20 May 2019.

Legendre, P. 2014. Interpreting the replacement and richness difference components of beta diversity: Replacement and richness difference components. Global Ecology and Biogeography, 23: 1324-1334.

Legendre, P., \& M. J. Anderson. 1999. Distance-based redundancy analysis: testing multispecies responses in multifactorial ecological experiments. Ecological Monography, 69: 1-24.

Lira, A. F. A., R. Badillo-Montaño, A. Lira-Noriega, \& C. M. R. Albuquerque. 2020. Potential distribution patterns of scorpions in north-eastern Brazil under scenarios of future climate change. Austral Ecology, 45: 215-228.

Lira, A. F. A., S. Í. A. Foerster, R. P. Salomão, T. J. Porto, C. M. R. Albuquerque, \& G. J. B. Moura. 2021a. Understanding the effects of human disturbance on scorpion diversity in Brazilian tropical forests. Journal of Insect Conservation, 25: 147-158.

Lira, A. F. A., J. C. Araújo, F. N. A. A. Rego, S. Í. A. Foerster, \& C. M. R. Albuquerque. 2021 b. Habitat heterogeneity shapes and shifts scorpion assemblages in a Brazilian seasonal dry tropical forest. Journal of Arid Environments, 186: 104413.

Lira, A. F. A., L. M. Pordeus, R. P. Salomão, R. Badillo-Montaño, \& C. M. R. Albuquerque. 2019b. Effects of anthropogenic land-use on scorpions (Arachnida: Scorpiones) in Neotropical forests. International Journal of Tropical Insect Science, 39: 211-218.

Lira, A. F. A., R. P. Salomão, \& C. M. R. Albuquerque. 2019a. Pattern of scorpion diversity across a bioclimatic dry-wet gradient in Neotropical forests. Acta Oecologica, 96: 10-17.

Liu, J., M. Vellend, Z. Wang, \& M. Yu. 2018. High beta diversity among small islands is due to environmental heterogeneity rather than ecological drift. Journal of Biogeography, 45: 2252-2261.

Losos, J. B. 2010. Adaptive radiation, ecological opportunity, and evolutionary determinism: American society of naturalists E. O. Wilson award address. The American Naturalists, 175: 623-639. 
Mahler, D. L., T. Ingram, L. J. Revell, \& J. B. Losos. 2013. Exceptional convergence on the macroevolutionary landscape in Island lizard radiations. Science, 341: 292-295.

Mahler, D. L., L. J. Revell, R. E. Glor, \& J. B. Losos. 2010. Ecological opportunity and the rate of morphological evolution in the diversification of greater Antillean Anoles: opportunity and rate in Anolis lizards. Evolution, 64: 2731-2745.

McArdle, B. H., \& M. J. Anderson. 2001. Fitting multivariate models to community data: a comment on distance-based redundancy analysis. Ecology, 82: 290-297.

MacArthur, R. H., \& E. O. Wilson. 1967. The theory of island biogeography. Princeton: Princeton University Press.

Myers, N., R. A. Mittermeier, C. G. Mittermeier, G. A. B. da Fonseca, \& J. Kent. 2000. Biodiversity hotspots for conservation priorities. Nature, 203: 853-858.

Mittelbach, G. G., \& D. W. Schemske. 2015. Ecological and evolutionary perspectives on community assembly. Trends in Ecology \& Evolution, 30: 241-247.

Mittermeier, R. A., P. R. Gil, M. Hoffman, J. Pilgrim, T. Brooks, C. G. Mittermeier, J. Lamoreux, G. A. B. da Fonseca, P. A. Seligmann, \& H. Ford. 2005. Hotspots revisited: Earth's biologically richest and most endangered terrestrial ecoregions conservation international, Mexico City. Conservation International Edition.

Moura, M. R., F. Villalobos, G. C. Costa, \& P. C. A. Garcia. 2016. Disentangling the Role of Climate, Topography and Vegetation in Species Richness Gradients. Plos One, 11: e0152468.

Naimi, B. 2015. usdm: Uncertainty Analysis for Species Distribution Models. URLhttps:// CRAN.R-project.org/package=usdm. R package version 1.1-15.

Nemésio, A., \& H. L. Vasconcelos. 2013. Beta diversity of orchid bees in a tropical biodiversity hotspot. Biodiversity and Conservation, 22: 1647-1661.

Oksanen, J., F. G. Blanchet, M. Friendly, R. Kindt, P. Legendre, D. McGlinn, P.R. Minchin, R. B. O’Hara, G. L. Simpson, P. Solymos, et al. 2019. vegan: Community Ecology Package. $\mathrm{R}$ package version 2.5-5. https:/CRAN.R-project.org/package=vegan. Accessed 20 May 2019.

Padial, A. A., F. Ceschin, S. A. Declerck, L. De Meester, C. C. Bonecker, F. A. Lansac-Tôha, J. R. Rodrigues, L. C. Rodrigues, S. Train, L. F. M. Velho, et al. 2014. Dispersal ability determines the role of environmental, spatial and temporal drivers of metacommunity structure. PloS One, 9: e111227.

Peres-Neto, P. R., P. Legendre, S. Dray, , \& D. Borcard, 2006. Variation partitioning of species data matrices: estimation and comparison of fractions. Ecology, 87: 2614-2625.

Polis, G. A. 1990. The Biology of Scorpions. Stanford: Stanford University Press. 
Prendini, L. 2001. Substratum specialization and speciation in southern African scorpion: the effect hypothesis revisited. In: Fet, V. and P. A. Selden, editors. Memoriam Gary A. Polis. Burnham Beeches: British Arachnological Society, p. 113-138.

Prendini, L. 2005. Scorpion diversity and distribution in southern Africa: pattern and process. In: Hubner, B. A., B. Sinclair and K. H. Lampe, editors. African Biodiversity: Molecules, Organisms, Ecosystems. New York: Springer, p. 25-68.

Prendini, L., \& T. L. Bird. 2008. Scorpions of the Brandberg Massif, Namibia: Species richness inversely correlated with altitude. African Invertebrates, 49: 77-107.

Qian, H., C. Badgley, \& D. L. Fox. 2009. The latitudinal gradient of beta diversity in relation to climate and topography for mammals in North America. Global Ecology and Biogeography, 18: $111-122$.

Ray-Mukherjee, J., K. Nimon, S. Mukherjee, D. W. Morris, R. Slotow, \& M. Hamer. 2014. Using commonality analysis in multiple regressions: a tool to decompose regression effects in the face of multicollinearity. Methods in Ecology and Evolution, 5: 320-328.

Richardson, D. M., \& R. J. Whittaker. 2010. Conservation biogeography - foundations, concepts and challenges: Conservation biogeography: foundations, concepts and challenges. Diversity and Distribution, 16: 313-320.

Ricklefs, R. E. 2004. A comprehensive framework for global patterns in biodiversity. Ecology Letters, 7: 1-15.

Rodriguez-Artigas, S. M., R. Ballester, \& J. A. Corronca. 2016. Factors that influence the beta-diversity of spider communities in northwestern Argentinean Grasslands. PeerJ, 4: e1946.

Rominger, A. J., K. R. Goodman, J. Y. Lim, E. E. Armstrong, L. E. Becking, G. M. Bennett, M. S. Brewer, D. D. Cotoras, C. P. Ewing, J. Harte, et al. 2016. Community assembly on isolated islands: macroecology meets evolution: Community assembly on isolated islands. Global Ecology and Biogeography, 25: 769-780.

Ruggiero, A., \& B. A. Hawkins. 2008. Why do mountains support so many species of birds? Ecography, 31: 306-315.

Schluter, D. 2000. The Ecology of Adaptive Radiation. Oxford: Oxford University Press.

Sepkoski, J. J. 1978. A kinetic model of Phanerozoic taxonomic diversity I. Analysis of marine orders. Paleobiology, 4: 223-251.

Simard, M., N. Pinto, J. B. Fisher, \& A. Baccini. 2011. Mapping forest canopy height globally with spaceborne lidar. Journal of Geophysical Research, 116: G04021.

Socolar, J. B., J. J. Gilroy, W. E. Kunin, \& D. P. Edwards. 2016. How Should Beta-Diversity Inform Biodiversity Conservation? Trends in Ecology and Evolution, 31: 67-80. 
Soininen, J., J. Heino, \& J. Wang. 2018. A meta-analysis of nestedness and turnover components of beta diversity across organisms and ecosystems. Global Ecology and Biogeography, 27: 96-109.

Stein, A., K. Gerstner, \& H. Kreft. 2014. Environmental heterogeneity as a universal driver of species richness across taxa, biomes and spatial scales. Ecology Letters, 17: 866-880.

Teruel, R., \& F. Kovař́k. 2012. Scorpions of Cuba. Praga: Clairon Production.

Teruel, R., \& T. M. Rodríguez-Cabrera. 2020. Revision of the genus Tityopsis Armas, 1974 (Scorpiones: Buthidae). Part 1. General updates and description of four new species. Euscorpius, 304: 1-40.

USGS. 2021. U.S. Geological Survey: Global 30 Arc-Second Elevation (GTOPO30). Accessed 19 November 2021. https://doi.org/10.5066/F7DF6PQS

Valdujo, P. H., A. C. O. Q. Carnaval, \& C. H. Graham. 2013. Environmental correlates of anuran beta diversity in the Brazilian Cerrado. Ecography, 36: 708-717.

Vasconcelos, H. L., J. M. S. Vilhena, K. G. Facure, \& A. L. K. M. Albernaz. 2010. Patterns of ant species diversity and turnover across $2000 \mathrm{~km}$ of Amazonian floodplain forest. Journal of Biogeography, 37: 432-440.

Volschenk, E. S., A. H. Burbidge, B. J. Durrant, \& M. S. Harvey. 2010. Spatial distribution patterns of scorpions (Scorpiones) in the arid Pilbara region of Western Australia. Records of the Western Australian Museum, 78: 271-284.

Warburg, M. R., \& A. Ben-Horin. 1981. The response to temperature gradients of scorpions from mesic and xeric habitats. Comparative Biochemistry and Physiology, 68: 277-279.

Zuur, A., E. N. Ieno, N. Walker, A. A. Saveliev, \& G. M. Smith. 2009. Mixed effects models and extensions in ecology with R. Springer Science \& Business Media.

Cómo citar: De Araujo-Lira, A. F., Araújo-Foerster, S. I., Medeiros-DeSouza, A., \& Armas, L. F. de (2022). Disentangling diversity patterns in Cuban scorpions (Arachnida: Scorpiones). Novitates Caribaea, (19), 72-91. https://doi.org/10.33800/nc.vi19.290. Original scientific article. 
Appendix 1. List of non-exotic scorpion species present in the Cuban archipelago. Data compiled from the Arachnological Collection of the Institute of Ecology and Systematics (Havana, Cuba) and also from the scientific literature

\begin{tabular}{|c|c|}
\hline Scorpion species & Sources \\
\hline \multicolumn{2}{|l|}{ Buthidae } \\
\hline Alayotityus delacruzi Armas, 1973 & Armas 1973 \\
\hline Alayotityus feti Teruel, 2004 & Teruel 2004 \\
\hline Alayotityus granma Armas, 1984 & Armas 1984 \\
\hline Alayotityus juraguaensis Armas, 1973 & Armas 1973 \\
\hline Alayotityus lapidocola Teruel, 2002 & Teruel 2002, 2004 \\
\hline Alayotityus nanus Armas, 1973 & Armas 1973; Teruel 2002 \\
\hline Alayotityus pallidus Teruel, 2002 & Teruel 2002, 2004 \\
\hline Alayotityus sierramaestrae Armas, 1973 & Armas 1973 \\
\hline Centruroides anchorellus Armas, 1976 & Teruel 2019 \\
\hline Centruroides arctimanus (Armas, 1976) & Armas 1976a \\
\hline Centruroides baracoae Armas, 1976 & Armas 1976a; Teruel 2000 \\
\hline Centruroides galano Teruel, 2001 & Teruel 2001b \\
\hline Centruroides guanensis Franganillo, 1930 & Teruel 2017 \\
\hline Centruroides melanodactylus Teruel, 2001 & Teruel 2001b \\
\hline Centruroides navarroi Teruel, 2001 & Teruel 2001b \\
\hline Centruroides nigropunctatus Teruel, 2006 & Teruel 2006c \\
\hline Centruroides polito Teruel, 2007 & Teruel 2007 \\
\hline Centruroides robertoi Armas, 1976 & Armas 1976a \\
\hline Centruroides spectatus Teruel, 2006 & Teruel 2006c \\
\hline Centruroides stockwelli Teruel, 2001 & Teruel 2001b \\
\hline Heteroctenus aridicola Teruel \& Armas, 2012 & Teruel and Armas 2012a \\
\hline Heteroctenus garridoi (Armas, 1974) & Teruel 2006b; Teruel and Armas 2012a \\
\hline Heteroctenus gibarae (Teruel, 2006) & Teruel 2006b; Teruel and Armas 2012a \\
\hline Heteroctenus granulimanus (Teruel, 2006) & Teruel 2006b; Teruel and Armas 2012a \\
\hline Heteroctenus junceus (Herbst, 1800) & Teruel and Armas 2012b \\
\hline Heteroctenus melloleitaoi (Teruel \& Armas, 2006) & Teruel and Armas 2006b; 2012a \\
\hline Microtityus difficilis Teruel \& Armas, 2006 & Teruel and Armas 2006c \\
\hline Microtityus farleyi Teruel, 2000 & Institute of Ecology and Systematics, Havana \\
\hline Microtityus flavescens Teruel, 2001 & Institute of Ecology and Systematics, Havana \\
\hline Microtityus fundorai Armas, 1974 & Teruel 2001a \\
\hline Microtityus guantanamo Armas, 1984 & Institute of Ecology and Systematics, Havana \\
\hline Microtityus jaumei Armas, 1974 & Institute of Ecology and Systematics, Havana \\
\hline Microtityus kovariki Teruel \& Infante, 2007 & Teruel and Infante 2007 \\
\hline Microtityus pusillus Teruel \& Kovarik, 2012 & Institute of Ecology and Systematics, Havana \\
\hline Microtityus trinitensis Armas, 1974 & Teruel 2001a; Teruel and Rodríguez 2014 \\
\hline
\end{tabular}


Appendix 1. Continuation

\begin{tabular}{|c|c|}
\hline Scorpion species & Sources \\
\hline Microtityus vulcanicus Teruel, 2019 & Institute of Ecology and Systematics, Havana \\
\hline $\begin{array}{l}\text { Tityopsis canizaresorum Teruel } \\
\text { \& Rodríguez-Cabrera, } 2020\end{array}$ & Teruel and Rodríguez-Cabrera, 2020 \\
\hline Tityopsis inaequalis (Armas, 1974) & Teruel and Rodríguez-Cabrera, 2020 \\
\hline Tityopsis inexpectata (Moreno, 1940) & Teruel and Rodríguez-Cabrera, 2020 \\
\hline Tityopsis mulata Teruel \& Rodríguez-Cabrera, 2020 & Teruel and Rodríguez-Cabrera, 2020 \\
\hline Tityopsis pumila Teruel \& Rodríguez-Cabrera, 2020 & Teruel and Rodríguez-Cabrera, 2020 \\
\hline Tityopsis sheylae Teruel \& Rodríguez-Cabrera, 2020 & Teruel and Rodríguez-Cabrera, 2020 \\
\hline \multicolumn{2}{|l|}{ Diplocentridae } \\
\hline Cazierius asper Teruel, 2006 & Teruel and Cala-Riquelme 2006; Teruel 2006a \\
\hline Cazierius chryseus Teruel \& Armas, 2006 & Teruel and Armas 2006a \\
\hline Cazierius granulosus Teruel, 2013 & Teruel 2013 \\
\hline Cazierius gundlachii (Karsch, 1880) & Teruel and Cala-Riquelme 2006; Teruel 2006a \\
\hline Cazierius paradoxos Teruel \& Díaz, 2004 & Teruel and Díaz 2004; Teruel 2006a \\
\hline Cazierius parvus Armas, 1984 & Teruel and Cala-Riquelme 2006; Teruel 2006a \\
\hline Cazierius torrei (Moreno, 1938) & Teruel and Armas 2006a \\
\hline Cryptoiclus rodriguezi Teruel \& Kovarik, 2013 & Teruel and Kovarik 2013 \\
\hline Didymocentrus armasi Teruel \& Rodriguez, 2008 & Teruel and Rodríguez 2008 \\
\hline Didymocentrus jaumei Armas, 1976 & Teruel and Rodríguez 2008 \\
\hline Didymocentrus sanfelipensis Armas, 1976 & Teruel and Rodríguez 2008 \\
\hline Didymocentrus trinitarius (Franganillo, 1930) & Teruel and Rodríguez 2008 \\
\hline Heteronebo bermudezi (Moreno, 1938) & Armas 1976b, 1984 \\
\hline Heteronebo morenoi (Armas, 1973) & Armas 1976b, 1984 \\
\hline Heteronebo nibujon Armas, 1984 & Teruel and Díaz 2004 \\
\hline
\end{tabular}

\section{LITERATURE CITED IN THIS APPENDIX}

Armas, L. F. 1973. Escorpiones del archipiélago cubano. I. Nuevo género y nuevas especies de Buthidae (Arachnida: Scorpionida). Poeyana, 114: 1-28.

Armas, L. F. 1976a. Escorpiones del archipiélago cubano. V. Nuevas especies de Centruroides (Scorpionida: Buthidae). Poeyana, 146: 1-55.

Armas, L. F. 1976b. Escorpiones del archipiélago cubano. VI. Familia Diplocentridae (Arachnida: Scorpionida). Poeyana, 147: 1-35.

Armas, L. F. 1984. Escorpiones del archipiélago cubano. VII. Adiciones y enmiendas (Scorpiones: Buthidae, Diplocentridae). Poeyana, 275: 1-37. 
Teruel, R. 2000. Taxonomía del complejo Centruroides anchorellus Armas, 1976 (Scorpiones: Buthidae). Revista Ibérica de Aracnología, 1: 3-12.

Teruel, R. 2001a. Taxonomía y distribución geográfica de Microtityus fundorai Armas, 1974 (Scorpiones: Buthidae) en la provincia Santiago de Cuba, Cuba. Revista Ibérica de Aracnología, 4: 29-33.

Teruel, R. 2001b. Tres nuevas especies de Centruroides (Scorpiones: Buthidae) de Cuba. Revista Ibérica de Aracnología, 3: 93-107.

Teruel, R. 2002. Taxonomía del complejo Alayotityus nanus Armas, 1973 (Scorpiones: Buthidae). Primera parte: descripción de dos nuevas especies. Revista Ibérica de Aracnología, 6: 187-194.

Teruel, R. 2004. Taxonomía del complejo Alayotityus nanus Armas, 1973 (Scorpiones: Buthidae). Segunda parte: descripción de una nueva especie. Revista Ibérica de Aracnología, 9: 259-268.

Teruel, R. 2006a. La subfamilia Diplocentrinae (Scorpiones: Scorpionidae) en Cuba. Segunda parte: nueva especie del género Cazierius Francke 1978. Boletín de la Sociedad Entomologica Aragonesa, 38: 87-93.

Teruel, R. 2006b. Apuntes sobre la taxonomía y biogeografía del género Rhopalurus Thorell 1876 (Scorpiones: Buthidae), con la descripción de dos nuevas especies de Cuba. Boletín de la Sociedad Entomologica Aragonesa, 38: 43-54.

Teruel, R. 2006c. Dos nuevos Centruroides Marx 1889 (Scorpiones: Buthidae) de Cuba Oriental. Boletín de la Sociedad Entomologica Aragonesa, 39: 83-90.

Teruel, R. 2007. Una nueva especie de Centruroides Marx 1890 del grupo "arctimanus" (Scorpiones: Buthidae) de Cuba oriental. Boletín de la Sociedad Entomologica Aragonesa, 40: $187-193$.

Teruel, R. 2013. La subfamilia Diplocentrinae (Scorpiones: Scorpionidae) en Cuba. Sexta parte: nueva especie de Cazierius Francke, 1978. Revista Ibérica de Aracnología, 23: 43-48.

Teruel, R. 2017. Actualización de la distribución geográfica en Cuba oriental de Centruroides guanensis Franganillo, 1931 (Scorpiones: Buthidae). Revista Ibérica de Aracnología, 31: $125-128$.

Teruel, R. 2019. Actualización de la distribución de Centruroides anchorellus Armas, 1976 (Scorpiones: Buthidae) en Cuba occidental. Revista Ibérica de Aracnología, 34: 157-159.

Teruel, R., \& D. Díaz. 2004. La subfamilia Diplocentrinae (Scorpiones: Scorpionidae) en Cuba. Primera parte: Heteronebo nibujon Armas 1984 y descripción de una especie nueva del género Cazierius Francke, 1978. Revista Ibérica de Aracnología, 9: 191-203.

Teruel, R., \& F. Cala-Riquelme. 2006. La subfamilia Diplocentrinae (Scorpiones: Scorpionidae) en Cuba. Cuarta parte: redescripciones de Cazierius gundlachii (Karsch 1880) y Cazierius parvus Armas 1984 y descripción del macho adulto de Cazierius asper Teruel 2006. Boletín de la Sociedad Entomologica Aragonesa, 39: 305-317. 
Teruel, R., \& F. Kovařík. 2013. Scorpions of Cuba. Praga: Clairon Production.

Teruel, R., \& L. F. Armas. 2006a. La subfamilia Diplocentrinae (Scorpiones: Scorpionidae) en Cuba. Tercera parte: dos nuevas adiciones al género Cazierius Francke 1978. Revista Ibérica de Aracnología, 38: 95-102.

Teruel, R., \& L. F. Armas. 2006b. Un nuevo Rhopalurus Thorell 1876 (Scorpiones: Buthidae) de Cuba oriental. Boletín de la Sociedad Entomologica Aragonesa, 39: 175-179.

Teruel, R., \& L. F. Armas. 2006c. Un nuevo Microtityus Kjellesvig-Waering 1966 (Scorpiones: Buthidae) de Cuba oriental. Boletín de la Sociedad Entomologica Aragonesa, 38: 113-116.

Teruel, R., \& L. F. Armas. 2012a. Nueva especie de Rhopalurus Thorell 1876 de Cuba oriental, con algunas consideraciones sobre sus congéneres antillanos (Scorpiones: Buthidae). Boletín de la Sociedad Entomologica Aragonesa, 50: 209-217.

Teruel, R., \& L. F. Armas. 2012b. Redescripción de Rhopalurus junceus (Herbst 1800) (Scorpiones: Buthidae). Boletín de la Sociedad Entomologica Aragonesa, 50: 153-174.

Teruel, R., \& L. M. Infante. 2007. Un nuevo escorpión del género Microtityus KjellesvigWaering 1966 (Scorpiones: Buthidae), de la región oriental de Cuba. Boletín de la Sociedad Entomologica Aragonesa, 40: 227-231.

Teruel, R., \& T. M. Rodríguez. 2008. La subfamilia Diplocentrinae (Scorpiones: Scorpionidae) en Cuba. Quinta parte: el género Didymocentrus Kraepelin 1905. Boletín de la Sociedad Entomologica Aragonesa, 42: 53-78.

Teruel, R., \& T. M. Rodríguez. 2014. On the westernmost occurrence of the genus Microtityus Kjellesvig-Waering, 1966 in Cuba (Scorpiones: Buthidae). Revista Ibérica de Aracnología, 24: $131-133$.

Teruel, R., \& T. M. Rodríguez-Cabrera. 2020. Revision of the genus Tityopsis Armas, 1974 (Scorpiones: Buthidae). Part 1. General updates and description of four new species. Euscorpius, 304: 1-40. 